\title{
Preliminary Study on Multi-Factors Affecting Adoption of E-Learning Systems in Universities: A Case of Open University of Tanzania (OUT)
}

\author{
Deogratius M Lashayo \\ Faculty of Information Science and Engineering (FISE), \\ Management \& Science University (MSU), Malaysia \\ \& \\ Faculty of Computer Science, Information Systems and Mathematics (FCIM), \\ The Institute of Finance Management (IFM), Tanzania \\ Email: mathew.deogratius@gmail.com \\ Md Gapar Md Johar \\ Management \& Science University (MSU), Shah Alam, Malaysia \\ Email: mdgapar@gmail.com; mdgapar@msu.edu.my
}

Received: 04 December 2017; Accepted: 15 January 2018; Published: 08 March 2018

\begin{abstract}
Literature show that there are limited factors for existing models in e-learning systems' adoption. This has raised an increasing sensible debate about factors affecting successful adoption of e-leaning systems in universities in developing world particularly in Tanzania. This preliminary study aimed at exploring multiple factors for successful adoption of e-learning systems in universities in learner perspective, using DeLone and McLean (2003) IS success model as a base model. This study was conducted by collecting data randomly, using the questionnaire from students of Open Universities of Tanzania (OUT) with response rate of 0.83 in a crosssectional study and later analyzed through content validity, reliability, and criterion-based predictive validity. The preliminary analysis shows that there are twelve distinctive factors affecting e-learning systems' adoption in universities in Tanzania. This finding suggests more empirical research studies to follow it up, to cement and generalize this case and validate the proposed model in large scale. The novelty of this research lies on the number and uniqueness of factors found.
\end{abstract}

Index Terms-E-learning systems, adoption, universities, factors, model, DeLone and McLean model, preliminary, Tanzania.

\section{INTRODUCTION}

There is a radical change in learning and teaching in institutions, this is due to the introduction of electronic learning systems [1]-[2]. Electronic learning system (here after called e-learning system) is regarded as a form of teaching and learning in which a web-enabled learning environment is created which provide a smooth transfer of knowledge content between tutor and learner or learner and learner in which an Internet is acting as a medium of networking (wired or wireless) between communicating digital devises and learning sessions may be either synchronous or asynchronous [3]-[4].The use of an Information Systems in learning and teaching together with the availability of electronic devises like computers and smart phones which are connected global using an Internet has revolutionized the education industry [5]. Adoption of e-learning system is the phenomenon of acceptance and use of web-enabled electronic learning system in education institutions for dissemination of learning contents [6]-[7]. The perceived benefits brought in by e-learning systems include saving time, saving cost, location-independent, increase of enrolment and chances of accessing education, sharing more contents, collaborative learning and personalised learning [8]-[9]. Watson and Watson in [10] comments that two most common categories of e-learning systems used in universities are Course Management Systems (CMS) and Learning Management Systems (LMS). Typical CMS are Blackboard, WebCT, Moodle, Sakai while that of LMS are Netdimension EKP and Oracle ilearning [10].

There are variations of adoption of e-learning systems in different parts of the world. The studies show that $65 \%$ of global universities have managed to adopt e-learning systems [11]. Isaacs and Hollow in [12] reported that 52\% of the total of 447 of respondents from developing countries has adopted e-learning systems, in African countries the studies show that only $49 \%$ of total of 358 respondents from 25 universities have adopted e-learning systems. In Sub-Saharan region in which Tanzania is a member, studies show that in 2011, five universities out of four countries had e-learning systems in place, two of those universities are from South Africa which are Cape Town University and the Nelson Mandela Metropolitan University, one university from Zambia, the University of 
Zambia, one university from Kenya, Nairobi University and one university in Uganda, Makerere University, were all found using Moodle-based e-learning systems [13].

There are significant investments in e-learning systems in universities [14]. Adkins in [14] reported that global investment in e-learning systems is nearly $7.6 \%$ of gross income. The Asia is a leader in terms of continental investment in e-learning systems with $17.3 \%$ of gross income, followed by Eastern Europe, Africa and Latin America with $16.9 \%, 15.2 \%$ and $14.6 \%$ respectively. Total amount invested in e-learning systems in 2011 was $\$ 250.9$ million which was expected to double to $\$ 512.7$ million by 2016 [14]. In an individual case of university investment, Winneba University of Education, in Ghana, e-learning system was priced at $\$ 20$ per student per annum with at least 15,000 students in 2008 [15].

Currently in Tanzania, the studies show that only $46 \%$ of total universities both public and private owned have e-learning systems in place [16]. Munguatosha et al. in [17] documented that $78 \%$ of Higher Learning Institutions (HLIs) in Tanzania have Moodle-based elearning systems. In another study in 2017, Lashayo and Gapar in [16] reported that the rate of Moodle based elearning systems in universities is $75 \%$. These literatures imply that irrespective of considerable e-learning systems' investments in universities but still the adoption is low, that is less than $50 \%$ of universities have adopted elearning systems and most universities prefer Moodle based e-learning system compared to other type.

Open University of Tanzania (OUT) is among a list of 33 full-fledged universities in Tanzania [18]. It has a well Information and Communication Technologies' (ICT) infrastructure connecting classrooms, staff's office, library and other resources centres in Tanzania regions [19]. It was one of the forefront adopter of e-learning system in 2009 because of the traditional mode of teaching and learning (open and distance learning) which was there before. The customized e-learning system in Open University of Tanzania is called "Moodle Learning Management System" [20]. Apart from having an elearning system, OUT has other Information Systems to manage students including the Student Academic Record Information System (SARIS) and Library Information System.

Recently, studies show that there are no comprehensive e-learning systems adoption models in universities particularly in Tanzania. Mohammadi in [21], Samarasinghe and Tretiakov in [22] claim that existence of limited factors is the main cause of incomprehensive of existing adoption models. This research aimed at addressing this problem by (1) Exploring the multiple factors which affect the adoption of e-learning systems in Tanzania from learner point of views (2) Systematically integrating the explored factors together into a successful adoption model. Specifically, the proposed multiple factors will preliminarily, quantitatively be tested against the views of students of Open University of Tanzania (OUT).
This article is organised in the following manner, first related works, in this section past research studies that deal with developing models for guiding adoption and evaluation of e-learning systems by extending DeLone and McLean (2003) model are critically analysed, then followed by methodology section, which describe different approaches used in gathering data for this preliminary study, Thereafter it continues with section of analysis, in this section exploration of factors affecting adoption of e-learning systems in Tanzania's universities has been analysed through content validity, reliability and criterion-based predictive validity. This article ends up with conclusion section, which describe the implication of findings to educational institutions.

\section{RELATEDWORKS}

There are varieties of models and frameworks in Information Systems and e-learning systems which have been used for years [23]. There are those which deals with individual behaviour of technology acceptance and those deals with organizations technology adoption and evaluation. Diffusion of Innovation (DOI) and Technology Organization Environment (TOE) and Delone and McLean (2003) they all dealing with firms' technology acceptance and Information Systems' models, DeLone and McLean (2003) model is developed specifically for Information System Success, unlike TOE and DOI [24], [25]. Lee and Lee in [26] documented that E-learning is a type of Information System (IS), based on that, this research study adapt DeLone and McLean (2003) model as the underlying model.

The DeLone and McLean (2003) model which was first developed in 1992 with six constructs as shown in figure 1, which are System Quality, Information Quality, Use, User Satisfaction, Individual Impact and Organizational Impact [27]. System Quality measure the design qualities of the information system itself, Information Quality measure the design qualities of the output of information system, the Use construct measure the actual (behavioural) use of the information system, the User Satisfaction measure the perceived user satisfaction from Information system with respect to its expectation, Individual Impact measure the impact the Information system brought to an immediate user and Organizational Impact measure the impact the system brought into the group, community or firm [27]. This model was referenced in more than 300 researches studies up to 2003 [24]. DeLone and McLean in [24] reported that changes in Information Technology (IT) industry caused the DeLone and McLean (1992) model to be updated ten years later by the same authors embracing suggestions from the studies which referenced it. Figure 2 shows the updated model.

Updated, DeLone and McLean (2003) model has maintain the same number of the constructs which are six as older version but with changes. Service Quality, which is the technical supports provided by IT department to 


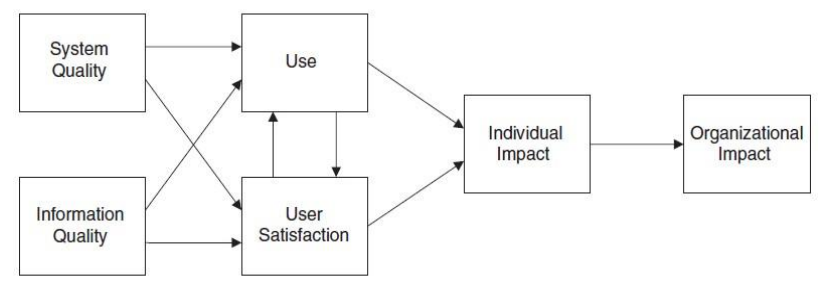

Fig.1. The DeLone and McLean (1992) model. Reprinted from The DeLone and McLean Model of Information Systems Success [27].

user of the system, this construct was added to DeLone and McLean (1992) model, the other construct which is Intention to Use was also added to it, this construct measure the voluntary use, Intention to Use and Use was fused together to provide a new construct which is called "Intention to Use/Use" which measure the voluntary and mandatory use of the system [24]. The impacts of the system are beyond the immediate individual impacts of user so the impacts are considered more as the organizational impacts and not only organisational impact, rather it is net benefits because impacts are positive and negative so the perceived differences between the two (positive impacts and negative impacts) are termed as Net Benefits [24]. The figure 2 depicts the updated model which is DeLone and McLean (2003) model. This model has been referenced in more than 3500 studies up to 2014 [28]. Furthermore, it has being used in $38 \%$ of the research studies in both IS and e-learning systems [29][30]. This strongly suggest that the model is reliable and strong to be used in both Information Systems' and elearning systems' studies.

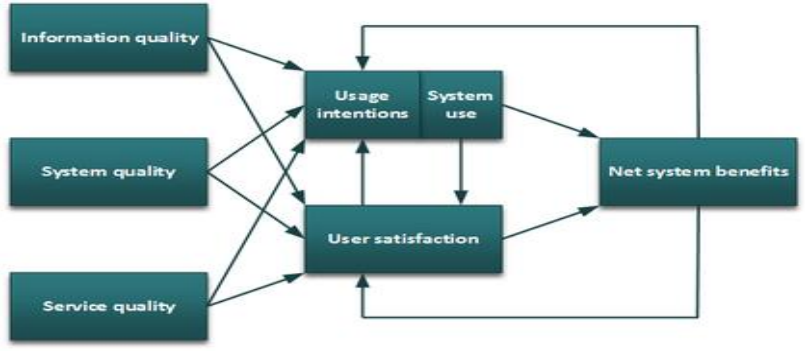

Fig.2. The updated DeLone and McLean (2003) model. Reprinted from The DeLone and McLean Model of Information Systems Success: A Ten-Year Update [24] (p. 24)

The DeLone and McLean (2003) model is neither comprehensive nor exhaustive as other developed models. It was observed to contain some weaknesses such as, it does not account for the Social aspects of systems, examples Trust of users and Social usefulness [31]. Also, it does not account for culture and contextual aspect [32][33]. These weaknesses were tried to be addressed by several research studies by extending it to make it more convenient, realistic and robust to the given environment. The following research studies were extending it: Holsapple and Lee-Post in [34], Lee-Post in [35], Ozkan and Koseler in [2], Hassanzadeh et al. in [30], Al-Sabawy in [36], Lwoga in [37], Mtebe and Raisamo in [28], Dorobă in [32], Mohammadi in [21] and Tossy in [38].

Holsapple and Lee-Post in [34] proposed the model with three themes: System Design and development which include: System Quality, Information Quality and Service Quality, other theme is System delivery themes which include: Use and User Satisfaction and the last theme was named System Outcome which include Net Benefits. This model was tested in 2009 by changing the position of User Satisfaction to be a part of last theme which is System Outcome, and tested in Kentucky University in United State of America (USA) using action research methodology and proved valid [35]. This model is limited in a sense that it is tested using the action research which can't be generalized. The other extension was done by Ozkan and Koseler in [2] in which the six constructs model was developed called HELAM and tested preliminarily in Turkey and later on in Brunel University in United Kingdom (UK). This extension was validated using an impact on User Satisfaction and also it employs 84 students from single university in UK in actual study. Hassanzadeh et al. in [30] developed a ten constructs model called MELSS and this model was tested in six universities in Iran and found valid. AlSabawy in [36] extended it to eight constructs and tested it in USA and found valid. Mtebe and Raisamo in [28] adopt DeLone and McLean (2003) model by changed the Intention to Use and Use and regarded it as "LMS Use" and tested it in University of Dar es Salaam (UDSM) in Tanzania, against 200 students and found it valid, same applied to Lwoga in [37] extended it with seven constructs and tested it in Muhimbili University of Health and Allied Science (MUCHS) and found it valid. Mohammadi in [21] extended it with nine constructs and tested it against sample from students from four universities and found valid. Tossy in [38] extended DeLone and McLean (1992) model with eight constructs and tested against 306 students from four universities in Tanzania and found valid.

Therefore, the differences of institutional cultures and user characteristics will help the researchers and practitioners to scale up the findings [9], on this note, this research studies explored twelve factors and empirically testing them at Open University in Tanzania (OUT) by adapting DeLone and McLean (2003) model.

\section{RESEARCH METHODOLOGY}

In the process of presenting an improved and customized model, this research study adapts DeLone and McLean (2003) Information System (IS) success model which was developed for IS and since e-Learning system is a type of IS designed for learning environment then this IS model is convenient for this study.

\section{A. Research Model}

The research model in figure 3 was developed by extending DeLone and McLean (2003) model. In this research model the following previous constructs from DeLone and McLean (2003) model are renamed: Information Quality is renamed to "Course Quality" and Net Benefits to "Perceived Benefits", the following constructs are broken down: System Quality to "Technical System Quality" and "Education System 
Quality", Intention to Use/Use to "Intention to Use" and "E-learning Actual Use". The following constructs are maintained as they are, Service Quality and Learner Satisfaction. The new constructs are added which are Trust, Environmental Factors, University Readiness, and Instructor Quality.

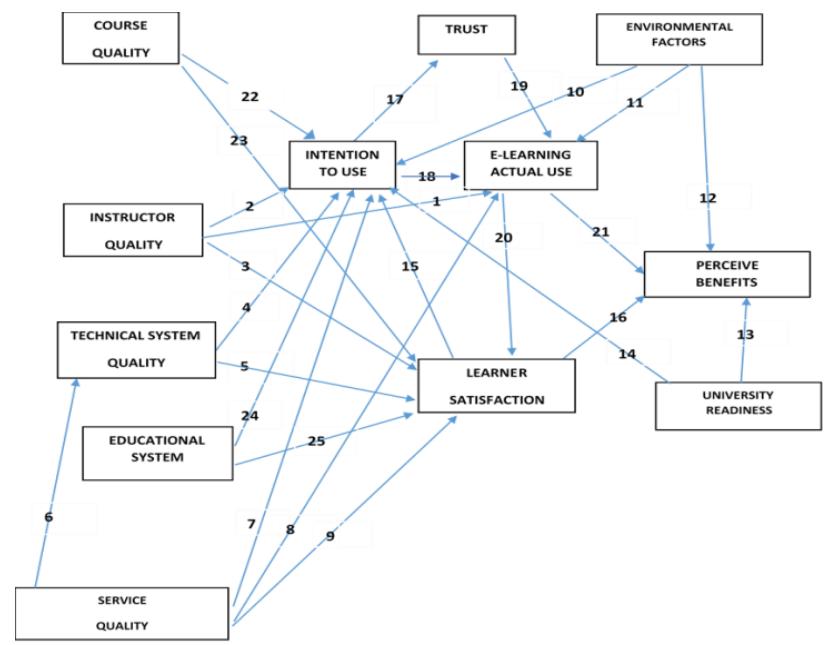

Fig.3. Research model

Components and Scale development for each construct with associated hypotheses and measuring instrument are described below:

\section{B. Construct and hypotheses definition}

Twelve constructs are proposed from extensive literature reviews with their respective relationship between themselves.

\section{1) Course Quality}

This construct measures information generated by the e-learning system particularly Course Information [24]. The studies show that Course Quality affect both learner satisfaction and Intention to Use in e-learning systems [30], [28]. This leads to the following hypotheses (Refer lines number $22 \& 23$ on figure 3 ).

H22: Course Quality positively and significant affect Intention to Use e-learning system.

H23: Course Quality positively and significant affect Learner satisfaction on e-learning system.

\section{2) Technical System Quality}

This construct measures typical information system's features, it includes all functionalities related to Information system [30]. The empirical research conducted by Mohammadi in [21], Hassanzadeh et al. in [30] show that Technical system quality positive affect the Intention to Use an e-learning system.

The following are hypotheses (Refer lines number 4 \& 5 on figure 3 ).

H4: Technical system quality positively and significant affect the Intention to Use e-learning system.

H5: Technical system quality positively and significant affect the Learner satisfaction on using e-learning system.

\section{3) Educational System Quality}

This construct measures typical educational features it includes all functionalities related to education [21], [30]. Theoretically, Educational system quality affect both Intention to Use e-learning and learner satisfaction with e-learning system [30], while the empirical study conducted by Mohammadi in [21] and Hassanzadeh et al. in [30] showed that Educational system quality affect User Satisfaction of e-learning system.

The following are hypotheses (Refer lines number 24 $\& 25$ on figure 3 ).

H24: Educational system quality positively and significant affect the Intention to Use e-learning.

H25: Educational system quality positively and significant affect the Learner satisfaction of using elearning system.

\section{4) Service Quality}

Service Quality is a combination of the all sort of technical services that the IT (Information Technology) technical staff offers to the users in the course of elearning adoption and continue use, most of the universities use a separate unit (IT unit) to support all sort of users of the e-learning system in the given institution [24]. The quality of support this unit is offering is so influential in continue use of e-learning system. The studies show that e-learning service quality positively affects learner satisfaction as well as e-learning intention to use [24], [30], [21]. The following are hypotheses (Refer lines number 6, 7, 8 \& 9 on figure 3 ).

H6: Service quality positively and significant affect Technical System Quality.

H7: Service quality positively and significant affect Intention to Use e-learning.

H8: Service quality positively and significant affect Elearning Actual Use.

H9: Service quality positively and significant affect Learner satisfaction.

\section{5) Intention to Use}

This construct measures a decision to use e-learning before you actually use it [30], [21]. Intention to use is an attitude [24]. Studies have investigated the relationship between Intention to Use and Actual e-learning Use and confirmed that Intention to Use e-learning system is a strong predictor of actual use and Trust [21]- [22].

The following are hypotheses (Refer lines number 17 $\& 18$ on figure 3 ).

H17: Intention to Use e-learning positively and significant affect learner Trust on e-learning.

H18: Intention to Use e-learning positively affect the E-learning Actual Use of the learner.

\section{6) Elearning Actual Use}

This is a construct which measure the extent of which the e-learning system (course elements, IT support, system) are actual accessed/used or the amount of effort spend in interacting with the e-learning [39]. This taxonomy (Elearning Actual Use) is most convenient in a 
setting where the usage of the e-learning is voluntary rather than mandatory [36].

The following are hypotheses (Refer line number 20 and 21 on figure 3 ).

H20: E-learning Actual Use positively and significant affect learner satisfaction on e-learning.

H21: E-learning Actual Use positively and significant affect Perceive benefits.

\section{7) Instructor Satisfaction}

This is the expectation of the learner on the adopted elearning system and also Learning is a social process, one of that player in socialization is the learner [11], [2]. Some studies had investigated the mediating effect of learner satisfaction on Intention to Use as dependence variable [40]- [41]. DeLone and McLean in [24], show that the perceive Learner satisfaction affect the use of elearning. Chiu, Chiu et al. in [41] insist that the Learner satisfaction and Learner intention to use are one of the essential constructs in e-learning system success. The following are hypotheses (Refer lines number $15 \& 16$ on figure 3).

H15: Learner satisfaction positively and significant affect learner Intention to Use e-learning.

H16: Learner satisfaction positively and significant affect Perceive benefits.

\section{8) Instructor Quality}

This is the instructor determination to use technology (functionalities provided by e-learning systems both generic functionalities and educational functionalities) will have the impact on e-learning [22]. Learning is a social process, one of that player in socialization is instructor [11], [2]. Instructor behaviour also has a significant impact on learner Intention to Use a system [37].

The following are hypotheses (Refer lines number 1, 2 \& 3 on figure 3 ).

H1: Instructor Quality positive and significant affects the E-learning Actual Use.

H2: Instructor Quality on e-learning positive and significant affect Intention to Use an e-learning system.

H3: Instructor Quality on e-learning positive and significant affects the Learner satisfaction over the elearning system.

\section{9) Environmental Factors}

This is the construct which measure the influence of external environments of the given university on elearning adoption, environments include other related universities, education partners, regulatory bodies, government, and customers [17]. Empirically, this had been ascertained by Roca et al. in [42] by combining two theories, TAM theory and Expectancy Disconfirmation theory (EDT) and found that external influence (environmental factors) directly affect satisfaction of the users on e-learning system. Sun, Tsai, Finger, Chen, and Yeh in [43] on perceived e-learner satisfaction, the environment dimension was made up of two main factors diversity in assessment and learner perceived interaction with others. The following are hypotheses (Refer lines number 10,11 and 12 on figure 3 ).

H10: Environmental factors positive and significant affect Learner satisfaction of e-learning.

H11: Environmental factors positive and significant affect E-learning Actual Use.

H12: Environmental factors positive and significant affect Perceive Benefits.

\section{0) University Readiness}

University Readiness is the way the internal structure of the organization is ready to accommodate the activities brought in by the IS application i.e. e-learning system [44]. Organizational readiness affects e-learning system [44]. Roca et al. in [42] claimed that the subjective norms which include the Interpersonal influence is one of the factor which affect the satisfaction of the users. The following are hypotheses (Refer lines number 13 and 14 on figure 3 ).

H13: University Readiness on e-learning positive and significant affect Intention to Use.

H14: University Readiness positive and significant affect Perceive Benefits.

\section{1) Trust}

Trust is the belief the trustor has on trustee that the exchange of learning contents between these two mutual parts will not exploit any of them, of which a trustee is web-based e-learning system and trustor is an instructor [45]. Trust is one of the key factors as social factor [32], [31]. In the environment of virtual learning whereby the learner and learner need to collaborate and learn together using the e-learning system, a degree of trust is so important among learners and between learners and system [46]. Ndume, Tillya and Twakiondo in [46] found that open education system in Tanzania is affected by trust. Kahiigi et al. in [47] mentioned that the Trust is a challenge in learner interaction in collaborative e-learning systems in Uganda. Also, Masa'deh, Tarhin, Mohamed and Maqableh in [48] argued that Trust has a social impact on Intention to Use e-learning systems.

The following is a hypothesis (Refer line number 19 on figure 3).

H19: Trust on e-learning positively and significant affect the E-learning Actual Use.

\section{2) Perceived Benefits}

This is the impact caused by the adopted e-learning to an individual, group, organizational and community [30]. As time goes on the impact is out of reach of an immediate user so it is about the entire organization at large as it perceives, just after adoption of e-learning system [49].

\section{Population and Sample}

This research study was conducted at Open University of Tanzania (OUT) between February to March, 2017. The learner model was tested against 97 respondents. A total of 97 usable questionnaires were obtained from a total of 120 distributed questionnaires of which a 100 
response were obtained.

Table 1. Usable data distribution

\begin{tabular}{|l|l|l|l|l|l|}
\hline \multicolumn{6}{|c|}{ Learner responses } \\
\hline \multirow{2}{*}{\multicolumn{2}{|c|}{}} & Frequency & Percent & $\begin{array}{l}\text { Valid } \\
\text { Percent }\end{array}$ & Cumulative \\
\hline \multirow{3}{*}{ Valid } & male & 51 & 52.6 & 52.6 & 52.6 \\
\cline { 2 - 6 } & female & 46 & 47.4 & 47.4 & 100.0 \\
\cline { 2 - 6 } & Total & 97 & 100.0 & 100.0 & \\
\hline
\end{tabular}

\section{ANALYSIS}

Linear regression is used to analyze the multiple factors. Johnson and Brooks in [50] and Yatigammana et al. in [7] suggested the minimum recommended sample size for a study of preliminary survey or scale development as 30, while the sample size for this preliminary study was 97 . Therefore, this study's sample size is higher than recommended size.

Statistically, sampling adequacy was proved by KaiserMayer-Olkin (KMO) and Bartlett's test of Sphericity using IBM SPSS version 21. The values of KMO obtained in 97 usable sample was 0.664 which is bigger than suggested minimum value of 0.6 [51].

Total variance explained (degree to which the preliminary study determines factors) in this study using Exploratory Factor Analysis (EFA) for a fixed twelve components/factors is $70.118 \%$ which is more than $60 \%$ recommended by Ozkan and Koseler in [2].

The three analysis techniques are employed in this analysis which are: Contents validity, Construct Reliability and criterion-based predictive validity.

\section{A. Construct Reliability}

Construct reliability test how consistence is a construct in measuring what is intending to measure [52]. The Cronbach Alpha $(\alpha)$ was used to test reliability of each construct/factor and result of reliability for the twelve constructs proposed were higher than minimum threshold of 0.7 [53]. The table 2 evidenced that the construct validity for each of proposed twelve factors were attained.

Table 2. Construct reliability (Cronbach's alpha)

\begin{tabular}{|l|l|l|}
\hline No & Construct & Cronbach's alpha $(\alpha)$ \\
\hline 1 & Course Quality (CQ) & 0.812 \\
\hline 2 & Technical System Quality (TSQ) & 0.746 \\
\hline 3 & Educational System Quality (ESQ) & 0.729 \\
\hline 4 & Service Quality (SQ) & 0.839 \\
\hline 5 & Intention to Use (ITU) & 0.792 \\
\hline 6 & Elearning Actual Use (EAU) & 0.806 \\
\hline 7 & Learner Satisfaction (LS) & 0.835 \\
\hline 8 & Instructor Quality (IQ) & 0.835 \\
\hline 9 & Environmental Factors (EF) & 0.778 \\
\hline 10 & University Readiness (UR) & 0.852 \\
\hline 11 & Trust (T) & 0.845 \\
\hline 12 & Perceived Benefits (PB) & 0.799 \\
\hline
\end{tabular}

\section{B. Content Validity}

The individual variable indicators for each construct are analysed using EFA using IBM SPSS version 21. Appendix A shows that most of the variable indicators (Factor loadings) are above 0.5, with exception of few cases that range between 0.3 to 0.5 which proves that individual items' validity measure a given construct [54].

\section{Criterion-based Predictive Validity}

In this analysis, the independent variables: Course Quality (CQ), Technical System Quality (TSQ), Education System Quality (ESQ), Instructor Quality (IQ), Service Quality (SQ), Intention to Use (ITU), E-learning Actual Use (EAU), Learner Satisfaction (LS), Trust (T), Environmental Factors (EF), Environmental Factors (EF) were analysed, their collective effectiveness to predict the adoption of e-learning system which was measured by the Perceived Benefits (PB).

All independent variables were entered into the analysis simultaneously in order to assess the predictive strength of the proposed model. When all independent variables were entered into the multiple regression model, results showed an $\mathrm{R}$ square of 0.62 and adjusted $\mathrm{R}$ square of 0.575 (Table 3) at p 0.0001 which is statistically significant. These findings accounted for $62 \%$ (adjusted $\mathrm{R}$ square $57.5 \%$ ) of the variance in Perceived Benefits [55]. This means that an overall capabilities of these factors to measure adoption is $57.5 \%$ for this preliminary study.

Table 3. Power of predictors variables to predict successful adoption

\begin{tabular}{|l|l|l|l|l|}
\hline \multicolumn{5}{|c|}{ Model summary } \\
\hline Model & $\mathrm{R}$ & $\begin{array}{l}\mathrm{R} \\
\text { Square }\end{array}$ & Adjusted R Square & $\begin{array}{l}\text { Significant } \\
(\mathrm{p})\end{array}$ \\
\hline 1 & 0.787 & 0.62 & 0.575 & 0.000 \\
\hline
\end{tabular}

a. Predictors: (Constant), T, ESQ, EF, SQ, IQ, TSQ, UR, LS, ITU, CQ

b. Dependent Variable: PB

Comparison of the results of this study and the previous studies in Tanzania.

Table 4 shows the latest empirical studies in learner perspective in Tanzania's universities (serial number 1 up to 3). The previous studies tried to explore the number of factors which affect successful adoption and evaluation of e-learning systems. This study went further by exploring twelve factors compared to the latest studies (refer serial number 4 of table 4 ).

Table 4. Latest studies in Tanzania's universities

\begin{tabular}{|l|l|l|l|}
\hline S/N & Author (s) & Year & No. of Valid Factors \\
\hline 1 & Mtebe and Raisamo & 2014 & 06 \\
\hline 2 & Lwoga & 2014 & 07 \\
\hline 3 & Tossy & 2017 & 08 \\
\hline 4 & Lashayo and Gapar & 2018 & 12 \\
\hline
\end{tabular}




\section{CONCLUSIONS}

The initial empirical findings indicate that there are multiple factors affecting e-learning systems in universities in Tanzania based on learner perceptions as shown in tables 2. The following twelve factors have been found which are: (1) Course Quality (CQ), (2)Technical System Quality (TSQ), (3) Educational System Quality (ESQ), (4) Instructor Quality (IQ), (5) Service Quality (SQ), (6) Intention to Use (ITU), (7) Elearning Actual Use (EAU), (8) Learner Satisfaction (LS), (9) Trust (T), (10) Environmental Factors (EF), (1I) University Readiness (UR) and (12) Perceived Benefits (PB) in a preliminary study on 97 students from Open University of Tanzania (OUT) as proposed in figure 3.

The significant difference between the number of distinctive factors found on this preliminary study with earlier studies as shown in serial number 4 of table 4 shows major contribution of this research.

This initiative opens up more rooms for researchers to validate these factors in large-scale studies in educational settings all over the world particular in developing countries.

\section{APPENDIX A FACTOR LOADING FOR EACH ITEMS}

\begin{tabular}{|c|c|c|c|}
\hline $\begin{array}{l}\text { Construct } \\
\text { No }\end{array}$ & Question no. & Question code & Factor loadings \\
\hline \multirow[t]{9}{*}{1} & Q.8 & CQ1 & 0.664 \\
\hline & Q.9 & CQ2 & 0.548 \\
\hline & Q.10 & $\mathrm{CQ3}$ & 0.563 \\
\hline & Q.11 & $\begin{array}{l}\text { CQ4 } \\
\end{array}$ & 0.539 \\
\hline & Q.12 & CQ5 & 0.514 \\
\hline & Q.13 & CQ6 & 0.615 \\
\hline & Q.14 & CQ7 & 0.473 \\
\hline & Q.15 & $\begin{array}{l}\text { CQ8 } \\
\end{array}$ & 0.831 \\
\hline & Q.16 & CQ9 & 0.546 \\
\hline \multirow[t]{5}{*}{2} & Q.17 & TSQ1 & 0.764 \\
\hline & Q.18 & TSQ2 & 0.565 \\
\hline & Q.19 & TSQ3 & 0.346 \\
\hline & Q.20 & TSQ4 & 0.531 \\
\hline & Q.21 & TSQ5 & 0.429 \\
\hline \multirow[t]{4}{*}{3} & Q.22 & ESQ1 & 0.710 \\
\hline & Q.23 & ESQ2 & 0.697 \\
\hline & Q.24 & ESQ3 & 0.512 \\
\hline & Q.25 & ESQ4 & 0.543 \\
\hline \multirow[t]{10}{*}{4} & Q.26 & SQ1 & 0.574 \\
\hline & Q.27 & SQ2 & 0.548 \\
\hline & Q.28 & SQ3 & 0.725 \\
\hline & Q.29 & SQ4 & 0.790 \\
\hline & Q.30 & SQ5 & 0.468 \\
\hline & Q.31 & SQ6 & 0.452 \\
\hline & Q.32 & SQ7 & 0.493 \\
\hline & Q.33 & SQ8 & 0.587 \\
\hline & Q.34 & SQ9 & 0.454 \\
\hline & Q.35 & SQ10 & 0.592 \\
\hline \multirow[t]{4}{*}{5} & Q.36 & ITU1 & 0.531 \\
\hline & Q.37 & ITU2 & 0.668 \\
\hline & Q.38 & ITU3 & 0.637 \\
\hline & Q.39 & ITU4 & 0.762 \\
\hline \multirow[t]{5}{*}{6} & Q.40 & EAU1 & 0.599 \\
\hline & Q.41 & EAU2 & 0.573 \\
\hline & Q.42 & EAU3 & 0.722 \\
\hline & Q.43 & EAU4 & 0.569 \\
\hline & Q.44 & EAU5 & 0.543 \\
\hline \multirow[t]{2}{*}{7} & $\mathrm{Q} 45$ & LS1 & 0.593 \\
\hline & Q.46 & LS2 & 0.579 \\
\hline
\end{tabular}

\begin{tabular}{|l|l|l|l|}
\hline \multirow{5}{*}{} & Q.47 & LS3 & 0.448 \\
\cline { 2 - 4 } & Q.48 & LS4 & 0.722 \\
\hline \multirow{5}{*}{} & Q.49 & IQ1 & 0.402 \\
\cline { 2 - 4 } & Q.50 & IQ2 & 0.419 \\
\cline { 2 - 4 } & Q.51 & IQ3 & 0.742 \\
\cline { 2 - 4 } & Q.52 & Q24 & 0.626 \\
\cline { 2 - 4 } & Q.53 & IQ5 & 0.724 \\
\hline 9 & Q.54 & EF1 & 0.596 \\
\cline { 2 - 4 } & Q.55 & EF2 & 0.649 \\
\cline { 2 - 4 } & Q.56 & EF3 & 0.603 \\
\cline { 2 - 4 } & Q.57 & EF4 & 0.768 \\
\hline 10 & Q.58 & UR1 & 0.605 \\
\cline { 2 - 4 } & Q.59 & UR2 & 0.592 \\
\cline { 2 - 4 } & Q.60 & UR3 & 0.709 \\
\cline { 2 - 4 } & Q.61 & UR4 & 0.663 \\
\cline { 2 - 4 } & Q.62 & UR5 & 0.678 \\
\hline 11 & Q.63 & T1 & 0.591 \\
\cline { 2 - 4 } & Q.64 & T2 & 0.602 \\
\cline { 2 - 4 } & Q.65 & T3 & 0.426 \\
\cline { 2 - 4 } & Q.66 & T4 & 0.531 \\
\hline \multirow{5}{*}{12} & Q.67 & PB1 & 0.627 \\
\cline { 2 - 4 } & Q.68 & PB2 & 0.502 \\
\cline { 2 - 4 } & Q.69 & PB3 & 0.379 \\
\cline { 2 - 4 } & Q.70 & PB4 & 0.600 \\
\cline { 2 - 4 } & Q.71 & PB5 & 0.566 \\
\hline \multirow{5}{*}{10} & &
\end{tabular}

\section{ACKNOWLEDGMENT}

Authors would like to thank the Institute of Finance Management (IFM) in Tanzania for funding this research study. We further extending our appreciation to Open University of Tanzania (OUT) for allowing the main author and his assistants to collect data from their students and staff.

\section{REFERENCES}

[1] E. Lwoga and M. Komba, "Antecedents of continued usage intentions of web-based learning management systems in Tanzania" Education+Training, pp.738-756, 2015, [Accessed: 03/05/2016], Available: doi:10.1108/ET-02-2014-0014.

[2] S. Ozkan, and R. Koseler, "Multi-dimensional Students' Evaluation of E-learning Systems in the Higher Education Context: An Empirical Investigation", Computers \& Education, vol.53, no.4, pp.1285-1296, 2009.

[3] T. Ahmed, "Toward Successful E-learning Implementation in Developing Countries:A proposed Model for Predicting and Enhancing Higher Educations' Participation", International Journal of Academic Research in Business and Social Sciences, vol.3, no.1, pp.422-425, 2013, [Online]. Available: http://www.hrmars.com/admin/pics/1485.pdf

[4] T. Monahan, G. McArdle, and M. Bertolotto, "Virtual reality for collaborative elearning", Computers \& Education, vol.50, pp.1339-1353, 2008.

[5] S. Wang, S. Liaw, \& Y.S. Wang. "Assessment of learner satisfaction with asynchronous electronic learning systems". Information Management Journal, vol. 41, no.1, pp.75-86, 2003.

[6] M.K. Maina, and D.M. Nzuki, "Adoption Determinants of E-learning Management System in Institutions of Higher Learning in Kenya: A Case of Selected Universities in Nairobi Metropolitan", International Journal of Business and Social Science, pp.233-248, 2015.

[7] K. Yatigammana, M.J.M. Gapar, and C. Gunawardhana, "Postgraduate Students' Perceived E-learning Acceptance: 
Model Validation", International Journal of Asian Business and Information Management, pp.51-60, 2013.

[8] U. Ehlers, "Web 2.0 - e-learning 2.0 - quality 2.0? Quality for new learning cultures", Quality Assurance in Education, vol.17, no.3, pp.296-314, 2009.

[9] A. Fidani, \& F. Idrizi, "Investigating students' acceptance of a learning management system in university education: a structural equation modeling approach", ICT Innovations 2012 Web Proceedings ISSN 1857-7288, pp. 311-320, 2012.

[10] W.R. Watson, and S.L. Watson, (2007), “An argument for clarity: what are learning management systems, what are they not, and what should they become? TechTrends", Springer Verlag, vol. 51, no.2, pp.28-34, 2007.

[11] M.Aparicio, F. Bacao, and T. Oliveira, "An e-Learning Theoretical Framework", Educational Technology \& Society, vol.19, no.1, pp.192-307, 2016, [Accessed: 20/06/2016], http://www.ifets.info/journals/19_1/24.pdf

[12] S. Isaacs, \& D. Hollow, "The eLearning Africa 2012 Report", ICWE, 2012.

[13] G. Ssekakubo, H. Suleman, and G. Marsden, "Issues of Adoption: Have E-Learning Management Systems Fulfilled their Potential in Developing Countries?", In Proceedings of the South African Institute of Computer Scientists and Information Technologists Conference on Knowledge, Innovation and Leadership in a Diverse Multidisciplinary Environment, pp. 231-238, 2011, Cape Town, South Africa.

[14] S. Adkins, "The Worldwide Market for Self-paced eLearning Products and Services: 2011-2016 Forecast and Analysis", 2013.

[15] T. Unwin, B. Kleessen, D. Hollow, J. Williams, L.M. Oloo, J. Alwala, I. Mutimucuio, F. Eduardo, and X. Muianga, "Digital Learning Management System in Africa: Myths and Realities", The Journal of Open and Distance Learning, vol.25, no.1, pp.5-23, 2010.

[16] D.M. Lashayo, and M.Gapar, "A review of e-learning systems' adoption in Tanzania universities", South East Asia Journal of Contemporary Business, Economics and Law, vol 13, no. 2, pp.111-118, (2017). [Accessed:03/10/2017]. Available: http://seajbel.com/wpcontent/uploads/2017/10/K13-252

[17] G.M. Munguatosha, B.M. Paul, and L. Thaddeus, "A social networked learning adoption model for higher education institutions in developing countries", On the Horizon, vol.19, no.4, pp.307 - 320, 2011.

[18] TCU Register-of-universities, [Accessed:03/10/2016], Available:

http://www.tcu.go.tz/images/documents/RegisteredUniver sity.pdf, 2016.

[19] E. Lwoga, "Making learning and Web 2.0 technologies work for higher learning institutions in Africa", CampusWide Information Systems, vol.29, no.2, pp.90-107, 2012.

[20] C. Mnyanyi, J. Bakari, \& T.S.A. Mbwete, "Implementing E-learning in Higher Open and Distance Learning Institutions in Developing Countries: The Experience of The Open University of Tanzania", Fifth International Conference of Learning International Networks Consortium (LINC), Massachusetts Institute of Technology Institute of Technology, 2010.

[21] H. Mohammadi, "Investigating users' perspectives on elearning: An integration of TAM and IS success model", Computers in Human Behavior, vol.45, pp.359-374, 2015.

[22] S.M. Samarasinghe, and A. Tretiakov, "eLearning system success in an organization context", (PhD dessertation), 2012, Palmerston North-New Zealand: Massey: Massey
University, [Accessed: 05/08/2016], Available: https://mro.massey.ac.nz/bitstream/handle/10179/4726/02 _whole.pdf

[23] T. Oliveira, and M. Martin, "Literature Reviews of Information technology adoption models at firm levels", The Electronic Journal Information Systems Evaluation, vol.1, pp.110-121, 2011.

[24] W. Delone, and E.R. McLean, "The DeLone and McLean Model of Information Systems Success: A Ten-Year Update", Journal of Management Information Systems, vol.19, no.4, pp.9-30, 2003. [Accessed:10/06/2016], Available:

http://citeseerx.ist.psu.edu/viewdoc/download?doi=10.1.1. $88.3031 \&$ rep=rep $1 \&$ type $=$ pdf

[25] L. Tornatzky and M. Fleischer, The process of technology innovation, Lexington, MA, Lexington Books, 1990.

[26] J.K. Lee, and W.K. Lee, "The relationship of e-Learner's self-regulatory efficacy and perception of e-Learning environmental quality", Computers in Human Behaviour, vol.24, pp.32-47, 2008.

[27] W. DeLone, and E. McLean, "Information System Success: The Quest for Dependable variable", Information Systems Research, vol.1, pp.60-95, 1992. [Accessed:10/06/2016], Available: https://pdfs.semanticscholar.org/a041/45f1ca06c61f5985a b22a2346b788f343392.pdf

[28] J.S. Mtebe, and R. Raisamo, "A model for assessing Learning Management System Success in higher education in sub-Saharan countries" The Electronic Journal of Information Systems in Developing Countries, vol.61, no.7, pp.1-17, 2014.

[29] C. Despont-Gros, H. Mueller, and C. Lovis, "Evaluating user interactions with clinical information systems: A model based on human-computer interaction models", Journal of Biomedical Informatics, vol.38, pp.244-255, 2005.

[30] A. Hassanzadeh, F. Kanaani, and S. Elahi, "A model for measuring e-learning systems success in universities", Expert Systems with Applications, vol.39, pp.1095910966, 2012.

[31] H. Lin, "Determinants of successful virtual communities: Contributions from system characteristics and social factors",Information \& Management, vol.45, no.8, pp.522-527, 2008. doi:10.1016/j.im.2008.08.002

[32] I. Dorobă, "Models for Measuring E-Learning Success in Universities: A Literature Review", Informatica Economică, vol.18, no.3, pp.77-89, 2014.

[33] Y.S. Wang, H.Y. Wang, and D.Y. Shee, "Measuring elearning systems success in an organizational context: Scale development and validation", Computers in Human Behavior, vol.23, pp.1792-1808, 2007.

[34] C.W. Holsapple, and A. Lee-Post, "Defining, Assessing, and Promoting E-Learning Success: An Information Systems Perspective", Decision Sciences Journal of Innovative Education, vol.4, no.1, pp.67-85, 2006.

[35] A. Lee-Post, "e-Learning Success Model: An Information Systems Perspective", Electronic Journal of e-Learning Volume, vol.7, no.1, pp.61-70, 2009.

[36] A. AL-Sabawy, "Measuring E-Learning Systems Success" ( $\mathrm{PhD}$ dessertation), University of Southern Queensaland, 2013. [Online], Available: https://eprints.usq.edu.au/27422/

[37] E.T. Lwoga, "Critical success factors for adoption of webbased learning management systems in Tanzania", International Journal of Education and Development using Information and Communication Technology, vol.10, no.1, pp.4-21, 2014. 
[38] T. Tossy, "Measuring the impacts of e-learning on students' achievements in learning process: An experience from Tanzania public universities", The Online Journal of Distance Education and e-Learning, vol.5, no.2, pp.61-68, 2017. [Online], Available: https://www.tojdel.net/journals/tojdel/articles/v05i02/v05i 02-08.pdf.

[39] Ramayah and Lee, "System Characteristics, Satisfactio and E-learning Usage: A Structural Equation Model (SEM)", The Turkish Online Journal of Educational Technology, vol.11, no.2, pp.196-206, 2012.

[40] J.C. Roca, \& M. Gagné, "Understanding e-learning continuance intention in the workplace: A selfdetermination theory perspective", Computers in Human Behavior, vol.24, pp.1585-1604, 2008.

[41] H.C. Wang, \& Y.F. Chiu, "Assessing e-Learning 2.0 systems success", Computers \& Education, vol.57, no.2, pp.1790-1800, 2011

[42] J. Roca, C. Chiu, and F. Martinez, "Under-standing elearning continuance intention: An extension of the Technology Ac-ceptance Model", International Journal of Human-Computer Studies, vol.64, no.8, pp.683-696, 2006.

[43] P.C. Sun, R.J. Tsai, G. Finger, Y.Y. Chen and D. Yeh, "What drives a successful e-Learning? An empirical investigation of the critical factors influencing learner satisfaction", Computers \& Education, vol.50, pp.11831202,2008

[44] A. Keramati, M. Afshari-Mofrad, \& A. Kamrani, "The role of readiness factors in E-Learning outcomes: An empirical study", Computers \& Education, vol. 57, pp.1919-1929, 2011, [Online], Available: https://pdfs.semanticscholar.org/0670/2f9ced315cac61a40 d6c6aeb036241771778.pdf

[45] P.A. Pavlou and M. Fygenson, "Understanding and Predicting Electronic Commerce Adoption: An Extension of the Theory of Planned Behavior", MIS Quarterly, vol.1, pp.115-143, 2011

[46] V. Ndume, F.N. Tillya, and F.N. Twaakiondo, "Challenges of Adaptive eLearning at Higher Learning Institutions: A Case Study in Tanzania", International Journal of Computing and ICT Research, vol.2, no.1, pp. $47-59,2008$.

[47] K.E. Kahiigi, H. Hansson, M. Danielson, F.F. Tusubira, \& M. Vesisenaho, "Collaborative e-learning in a developing country: A university case study in Uganda", The 10th European Conference on e-Learning ECEL 2011, Brighton, United Kingdom.

[48] R. Masa'deh, A. Tarhini, A.B. Mohammed, \& M. Maqableh, "Modeling Factors Affecting Student's Usage Behaviour of E-Learning Systems in Lebanon", International Journal of Business and Management, vol.11, no.2, pp.299-312, 2016.

[49] J.B. Raouf, I.S. Naser, and B.K. Jassim, "Determinants of E-Learning Implementation Success in the Iraqi MoHE", Eng. \&Tech. Journal, vol.30, no.4, pp.659-671, 2012.
[50] G.A. Johanson, \& G.P. Brooks, G. P, "Initial scale development: Sample size for pilot studies", Educational and Psychological Measurement, vol.70, pp.394-400, 2010, [Online], Available: doi:10.1177/0013164409355692

[51] H.F. Kaiser, "An index of factorial simplicity", Psychometrika, vol.39, no.1, pp.31-36, 1974.

[52] D. Ary, L.C. Jacobs, \& A. Razavieh, Introduction to research in education, 4th ed, Fort Worth, TX: Holt, Rinehart, and Winston, 1990.

[53] J.F. Hair, W.C. Black, B.J. Babin, and R.E.Anderson, Multivariate Data Analysis, 7th Edition, Upper Saddle River, New Jersey: Prentice Hall, 2010.

[54] T.Brown, Comfirmatory Factor Analysis for Applied Research, 2nd edition, New York: The Guilford Press, 2015.

[55] J. Cohen, Statistical power analysis for the behavioral sciences, 2nd ed, Hillsdale NJ: Erlbaum, 1988.

\section{Authors' Profiles}

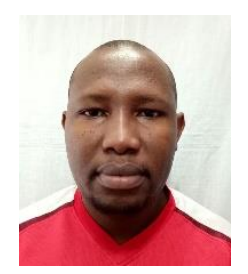

Deogratius M Lashayo received his Master's degree in Software Systems and Internet Technology from University of Sheffield in United Kingdom and he is now pursuing his $\mathrm{Ph}$. D degree in Faculty of Information Science and Engineering at Management and Science University (MSU) in Malaysia. His major research interests include Information Systems Management, Enterprise Applications Integration (EAI) and Educational Technologies. He is reachable at mathew.deogratius@gmail.com

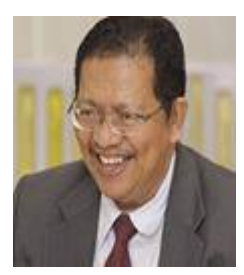

Prof. Dato' Dr. Md Gapar Md Johar, $\mathrm{He}$ is Senior Vice President Research, Innovation, Technology and System of Management and Science University, Malaysia. He is a professor in Software Engineering.

$\mathrm{He}$ holds $\mathrm{PhD}$ in Computer Science, MSc in Data Engineering and BSc (Hons) in Computer Science. $\mathrm{He}$ is a Certified E-Commerce Consultant.

He has more 35 years of working experience and worked in various organizations such as Ministry of Finance, Ministry of Public Enterprise, Public Service Department, Glaxo Malaysia Sdn Bhd and Management \& Science University.

His research interests include learning content management system, knowledge management system, data mining, ecommerce, image processing, data science, character recognition and healthcare management system.

$\mathrm{He}$ is reachable at mdgapar@gmail.com or gapar@msu.edu.my

How to cite this paper: Deogratius M Lashayo, Md Gapar Md Johar, " Preliminary Study on Multi-Factors Affecting Adoption of E-Learning Systems in Universities: A Case of Open University of Tanzania (OUT)", International Journal of Modern Education and Computer Science(IJMECS), Vol.10, No.3, pp. 29-37, 2018.DOI: 10.5815/ijmecs.2018.03.04 